\title{
Analysis of sports management students' opinions on project-based learning
}

\author{
Ahmet SAHIN \\ Mehmet Akif Ersoy University, The School of Physical Education and Sports, Burdur, Turkey \\ Address Correspondence to A. Sahın, e-mail: asahin@mehmetakif.edu.tr
}

\begin{abstract}
The purpose of this study is to analyze Sports Management Students' Opinions on Project-Based Learning. A great majority of the sports management students who participated in the study do sports regularly and only a little portion of $3.3 \%$ stated that they do not do sports at all. In order to determine the attitudes of students towards the method of Project-Based Learning, an attitude scale -originally called Project-Based Learning Attitude Scale (PBLAS), which consisted of a total of 26 items (13 positive and 13 negative) was prepared after receiving the expert opinion of Sezgin in 2008. The ratio of female sports management students who read books is higher that the ratio of male students. On the other hand, the frequency of visiting entertainment venues is higher for male students compared to female students. When the average scores of the answers given to the Project-Based Learning scale are observed, it can be concluded that the students who participated in the study were eager to make use of the benefits of project-based learning, however because they were also affected from negative cases, they were often undecided. When the opinions of the project-based learning study participants are analyzed according to gender, it can be claimed that for the 4 items that were available in the scale, male students had more positive opinions compared to female students. It can be also seen that more female students expressed positive opinions for item first.
\end{abstract}

Keywords: Sports Management, Students, Project-Based Learning.

\section{INTRODUCTION}

A project involves the activities of developing a design or designing, imagining, and planning $(9,17)$. Project management, which emerged in the fields of architecture and engineering towards the end of the $16^{\text {th }}$ century, was first applied in art schools that were established in Rome in 1577, in the days of Pope Gregory XIII. Project management applications in Europe were initiated before 1830 in Moscow, where project management was applied for the education of engineers and craftsmen $(2,11,13)$. In the US, project management was brought into practice in 1920 by Bennet (11). Project management in education was first applied in agriculture and home economics courses during the 1900's and quickly became widespread (8). Projects allow students to learn through experience and to acquire skills in carrying out scientific research (19). ProjectBased Learning is a project centered approach (22). It is described as a long-termed work carried out by students, either individually by themselves or collectively in small groups, with the purpose of obtaining a given product. The basic purpose of projects is to help students become responsible for their own learning and motivate them to work in collaboration with others (18). Projects support interdisciplinary studies and genuine learning products by allowing the establishment of studentfocused classrooms (5). Project-based learning finds its roots in the progressivist philosophical trend and takes inspiration from Dewey's constructivism, Kilpatrick's concept of project management, Bruner's approach of learning through discovery, and finally Thelen's group investigation model (1, 14). Project-based learning helps students to make connections with real life, learn beneficial information, and realize persistent learning. It is also a model that shapes learning into a more functional form (21).

In our country, project-based learning is mostly applied in primary and intermediary education institutions and research carried out on this subject is mostly on applications in primary and intermediary level education $(3,4,7,10,12,23)$. There are new studies in the foreign literature on project-based learning applications in higher education as well $(15,16)$.

\section{MATERIAL \& METHOD}

Research design and analysis 
The results that were obtained in the study were evaluated using the statistical methods available in the SPSS 14.0 Software Package. In the study results and evaluation section the following were presented: the frequency distribution of the demographic characteristics of the study participants; the means and the standard deviation values of the questions concerning opinions on project-based learning, and the reliability analysis used to determine the suitability of the data for statistical analysis.

Since it was observed that the data had a normal distribution after performing a normality test, parametric tests were applied in order to determine significant differences among groups for selected independent variables. In order to determine whether there were differences between two groups for the independent variables gender and the status of doing sports, an Independent Sample $\mathrm{T}$ test was used. In order to determine whether there were significant differences between more than two groups, One-Way ANOVA test was applied.

\section{Sample and sampling}

The sample consisted of a total of 150 sports management students 44 female and 106 male students, who were enrolled in the 2015-2016 Fall semester in the Usak University Faculty of Sports Sciences located in the Usak Province. The students were subjected to a questionnaire using the random method.

\section{Reliability analysis}

\section{RESULTS}

The results obtained in this study were shown in tables.
The reliability analysis of the 26-question scale gave an internal consistency value of 0.69 Cronbach's alpha.

\begin{tabular}{ccc}
\multicolumn{3}{c}{ Reliability Statistics } \\
\hline $\begin{array}{c}\text { Cronbach's } \\
\text { Alpha }\end{array}$ & $\begin{array}{c}\text { Cronbach's Alpha } \\
\text { Based on } \\
\text { Standardized Items }\end{array}$ & N of Items \\
\hline 0.694 & 0.695 & 26 \\
\hline
\end{tabular}

\section{Data collection}

In order to determine the attitudes of students towards the method of Project-Based Learning, an attitude scale -originally called Project-Based Learning Attitude Scale (PBLAS), which consisted of a total of 26 items (13 positive and 13 negative) was prepared after receiving the expert opinion of Sezgin (20).

In this study, an attitude scale consisting of a total of 26 items (13 positive and 13 negative) was prepared in order to determine the attitudes of students towards project-based learning method. The scale was a Likert-type scale and the grading of the items was carried out using a grading system with 5 points (strongly agree, agree, indecisive, disagree, and strongly disagree). The answers given for the positive items were graded as Strongly Agree $=5$, Agree $=4$, Undecided $=3$, Disagree $=2$, Strongly Disagree $=1$, while the answers given for the negative items were graded as Strongly Agree=1, Agree $=2$, Undecided $=3$, Disagree $=4$, Strongly Disagree $=5$. The total attainable score in the attitude scale used in the study was 130 and the score attainable by marking only the "undecided" answer was 78 .

Table 1. One-Way ANOVA test results showing whether there is a difference in the opinions of Sports

Management students on project-based learning according to the self-description variable

\begin{tabular}{lcccc}
\hline & Sum of Squares & Mean Squares & F & P \\
\hline $\begin{array}{l}\text { 16. PBL Applications increase anxiety levels towards } \\
\text { the lesson. }\end{array}$ & 10.822 & 3.607 & 4.924 & 0.003 \\
\hline $\begin{array}{l}\text { 19. There is no need for teachers who carry out the } \\
\text { PBL Applications to be experienced." }\end{array}$ & 6.187 & 2.062 & 2.472 & 0.044 \\
\hline 22. PBL Applications have no effect on motivation. & 9.199 & 3.066 & 3.570 & 0.016 \\
\hline P $<0.05$ & & & &
\end{tabular}

When the opinions of sports management students on Project-Based Learning (PBL) according to their description of themselves were evaluated, significant differences were found between groups

"There is no need for teachers who carry out the PBL Applications to be experienced." statement in the $19^{\text {th }}$ item and the "PBL Applications have no effect on motivation" statement in the $22^{\text {nd }}$ item (Table 1 ). for the "PBL Applications increase anxiety levels towards lessons." statement in the $16^{\text {th }}$ item; the 
Table 2. Tukey test results showing the differences in the opinions of Sports Management students on project-based learning according to the self-description variable

\begin{tabular}{|c|c|c|c|c|}
\hline Variables & $\begin{array}{c}\text { (I) Self- } \\
\text { Description } \\
\end{array}$ & (J) Self-Description & $\begin{array}{c}\text { Difference Between } \\
\text { Means (I-J) }\end{array}$ & $\mathrm{P}$ \\
\hline \multirow{3}{*}{$\begin{array}{l}\text { 16. PBL Applications increase } \\
\text { anxiety levels towards the } \\
\text { lesson. }\end{array}$} & $\begin{array}{l}\text { Hyperactive, } \\
\text { active }\end{array}$ & Quiet and calm & 0.367 & 0.224 \\
\hline & & Social, extrovert & 0.628 & 0.010 \\
\hline & & Nervous, "hot-blooded" & 0.777 & 0.005 \\
\hline \multirow{3}{*}{$\begin{array}{l}\text { 19. There is no need for teachers } \\
\text { who carry out the PBL } \\
\text { Applications to be experienced." }\end{array}$} & Quiet and calm & Social, extrovert & 0.284 & 0.444 \\
\hline & & Hyperactive, active & 0.542 & 0.043 \\
\hline & & Nervous, "hot-blooded" & 0.326 & 0.476 \\
\hline \multirow{3}{*}{$\begin{array}{l}\text { 22. PBL Applications have no } \\
\text { effect on motivation. }\end{array}$} & Quiet and calm & Social, extrovert & 0.494 & 0.045 \\
\hline & & Hyperactive, active & 0.531 & 0.044 \\
\hline & & Nervous, "hot-blooded" & 0.554 & 0.079 \\
\hline
\end{tabular}

For the "PBL Applications increase anxiety levels towards lessons." statement, significant difference was observed between those who defined themselves as active, those who defined themselves as social and extroverts, and those who defined themselves as nervous. According to this, it can be concluded that regarding this item, the opinions of those who consider themselves as active are more positive compared to those who consider themselves as extroverts and those who consider themselves as nervous. There were no significant differences between those who defined themselves as quiet and calm and those who defined themselves as active for the "There is no need for teachers who carry out the this statement, the opinions of those who define themselves as quiet and calm are significantly more positive compared to those who define themselves as active. For the "PBL Applications have no effect on motivation." statement, significant differences were observed between those who defined themselves as quiet and calm, those who defined themselves as extroverts, and those who defined themselves as active. According to this, it can be concluded that regarding this statement, the opinions of those who define themselves as quiet and calm are significantly more positive compared to those who define themselves as extroverts (Table 2).

PBL Applications to be experienced." statement. According to this, it can be concluded that regarding

Table 3. Tukey test results showing the differences in the opinions of Sports Management students on project-based learning according to the book reading frequency variable

\begin{tabular}{|c|c|c|c|c|}
\hline Variables & $\begin{array}{l}\text { (I) Book Reading } \\
\text { Frequency }\end{array}$ & $\begin{array}{l}\text { (J) Book Reading } \\
\text { Frequency }\end{array}$ & $\begin{array}{c}\text { Difference Between } \\
\text { Means (I-J) }\end{array}$ & $\mathbf{P}$ \\
\hline \multirow{3}{*}{$\begin{array}{l}\text { 14. PBL Applications are complex } \\
\text { and difficult because they require } \\
\text { the use of a wide variety of teaching } \\
\text { materials. }\end{array}$} & Once per 2 weeks & Once per week & -0.452 & 0.269 \\
\hline & & $\begin{array}{c}\text { I rarely read } \\
\text { books }\end{array}$ & -0.587 & 0.044 \\
\hline & & $\begin{array}{c}\text { I never read } \\
\text { books }\end{array}$ & -0.799 & 0.045 \\
\hline \multirow{3}{*}{$\begin{array}{l}\text { 17. There is no need to share } \\
\text { information during PBL } \\
\text { Applications. }\end{array}$} & $\begin{array}{c}\text { I rarely read } \\
\text { books }\end{array}$ & Once per week & -0.208 & 0.688 \\
\hline & & Once per 2 weeks & -0.202 & 0.799 \\
\hline & & $\begin{array}{c}\text { I never read } \\
\text { books }\end{array}$ & -0.743 & 0.022 \\
\hline
\end{tabular}

$\mathrm{P}<0.05$ means a significant difference.

For the "PBL Applications are complex and difficult because they require the use of a wide variety of teaching materials." statement, significant differences were observed for those who read books once in two weeks, those who rarely read books, and those who never read books. According to this, it can be concluded that regarding this statement, the opinions of those who read books once in two weeks are significantly more negative compared to those who rarely read books, and those who never read books.
For the "There is no need to share information during PBL Applications." statement, a significant difference was observed for those who rarely read books and those who never read books. According to this, it can be concluded that regarding this statement, the opinions of those who rarely read books are significantly more negative compared to those who never read books (Table 3). 
Table 4. Tukey test results showing the differences in the opinions of Sports Management students on project-based learning according to the variable of Weekly time spent for sports

\begin{tabular}{|c|c|c|c|c|}
\hline Variables & $\begin{array}{l}\text { (I) Weekly time } \\
\text { spent for sports }\end{array}$ & $\begin{array}{l}\text { (J) Weekly time } \\
\text { spent for sports }\end{array}$ & $\begin{array}{c}\text { Difference } \\
\text { Between Means } \\
(\mathrm{I}-\mathrm{J}) \\
\end{array}$ & $\mathrm{P}$ \\
\hline \multirow{3}{*}{$\begin{array}{l}\text { 13. PBL Applications are important } \\
\text { as they include various teaching } \\
\text { instruments. }\end{array}$} & 3-4 hours & 1-2 hours & 0.680 & 0.013 \\
\hline & & 5-8 hours & 0.591 & 0.010 \\
\hline & & 9 hours and more & 0.469 & 0.104 \\
\hline \multirow{3}{*}{$\begin{array}{l}\text { 14. PBL Applications are complex } \\
\text { and difficult because they require } \\
\text { the use of a wide variety of teaching } \\
\text { materials. }\end{array}$} & 3-4 hours & 1-2 hours & 0.251 & 0.695 \\
\hline & & 5-8 hours & 0.167 & 0.825 \\
\hline & & 9 hours and more & 0.593 & 0.030 \\
\hline
\end{tabular}

$\mathrm{P}<0.05$ means a significant difference.

For the "PBL Applications are important as they include various teaching instruments." statement, significant differences were observed for those who spent 3-4 hours weekly for sports, those who spent 1-2 hours weekly for sports, and those who spent 5-8 hours weekly for sports. According to this, it can be concluded that regarding this statement, the opinions of those whose weekly time spent on sports is 3-4 hours are significantly more positive compared to those whose weekly time spent on sports is either 1-2 hours or 5-8 hours. For the "PBL
Applications are complex and difficult because they require the use of a wide variety of teaching materials." statement, a significant difference was observed for those who spent 3-4 hours weekly for sports and those who spent 9 hours or more weekly for sports. According to this, it can be concluded that regarding this statement, the opinions of those whose weekly time spent on sports is 3-4 hours is significantly more positive compared to those whose weekly time spent on sports is 9 hours or more (Table 4).

Table 5. Tukey test results showing the differences in the opinions of Sports Management students on project-based learning according to age groups

\begin{tabular}{|c|c|c|c|c|}
\hline Variables & (I) Age & (J) Age & $\begin{array}{l}\text { Difference Between } \\
\text { Means (I-J) }\end{array}$ & $\mathrm{P}$ \\
\hline \multirow{3}{*}{$\begin{array}{l}\text { 4. PBL Applications are highly beneficial in the } \\
\text { education process of students. }\end{array}$} & $22-23$ & $18-19$ & 0.321 & 0.424 \\
\hline & & $20-21$ & 0.304 & 0.415 \\
\hline & & $24-25$ & 0.966 & 0.013 \\
\hline \multirow{3}{*}{$\begin{array}{l}\text { 23. PBL Applications have no beneficial effect on } \\
\text { the education process of students. }\end{array}$} & $18-19$ & $20-21$ & 0.475 & 0.035 \\
\hline & & $22-23$ & 0.513 & 0.081 \\
\hline & & $24-25$ & 0.081 & 0.993 \\
\hline
\end{tabular}

$\mathrm{P}<0.05$ means a significant difference.

For the "PBL Applications are highly beneficial in the education process of students." statement, a significant difference was found between students in the age group of 22-23 and the students in the age group of 24-25. According to this, it can be concluded that regarding this statement, the opinions of students in the 22-23 age group are significantly more positive compared to those in the 24-25 age group. For the "PBL Applications have no beneficial effect on the education process of students." statement, a significant difference was found between students in the age group of 18-19 and the students in the age group of 20-21. According to this, it can be concluded that regarding this statement, the opinions of students in the 18-19 age group were significantly more positive compared to those in the 20-21 age group (Table 5).

\section{DISCUSSION}

A great majority of the sports management students who attended the study do sports regularly and only a little portion of $3.3 \%$ stated that they do not do sports at all.

The ratio of female sports management students who read books is higher that the ratio of male students. On the other hand, the frequency of visiting entertainment venues is higher for male students compared to female students. When the average points of the answers given to the ProjectBased Learning scale are observed, it can be concluded that the students who attended the study are eager to make use of the benefits of project-based learning, however because they are also affected from negative cases, they are often uncertain.

It was observed that, as expected, people who had to make decisions regarding Project-Based Learning had improved metacognition skills (6). In his study, Kalaycı (12) concluded that students should decide freely as this is an important 
experience with respect to acquiring a decision making skill. When the opinions of the project-based learning study participants are analyzed according to gender, it can be claimed that for the 4 items that were available in the scale, male students had more positive opinions compared to female students. It can be also seen that more female students expressed positive opinion for item (1).

When the differences among groups were observed according to the age independent variable, significant differences were found for two items and it was observed that the opinions of younger participants on project-based learning were more positive compared to higher-age groups.

When the differences among groups were observed according to the time spent on sports, significant differences were found -although not too high- for two items, between those who spent 3-4 hours on sports and those who spent more time on sports. In his study, Acar (2) concluded that projectbased learning had a significant effect on professional athletes and this result supports the results obtained in our study.

Although the differences between groups according to the book reading frequency independent variable were not very big, significant differences were observed for 2 items used in the study between those who rarely read books and those who read books once in two weeks. For the self-description variable, differences were obtained between the groups for 3 items.

\section{REFERENCES}

1. Acar EN. The Effect of Project-Based Learning on the Scientific Process Skills of Science Teachers and their Attitude towards Biology, (Unpublished master thesis). Canakkale, Canakkale Onsekiz Mart University, 2011.

2. Acar $G$ The effect of project-based learning on students' motivation. International Journal of Academic Research, 2013; $5(2): 82-86$.

3. Aladag S. The Effect of Project-Based Learning Approach on the Academic Success Level of Students in Primary Education Mathematics Teaching, (Unpublished master thesis). Ankara, Gazi University, 2005.

4. Balki AG. Evaluation of the Application of the Project-Based Learning Method by Konya Esentepe Elementary Private School, (Unpublished master thesis). Konya, Selcuk University, 2003.

5. Blumenfeld P, Soloway E, Marx RA. Motivating project based learning: sustaining the doing supporting the learner. Educational Psychologist, 1991; 26(3-4):369-398.

6. Cohen MS, Freeman JT, Wolf S. Meta cognition in time stressed decision making: Recognizing, critiquing, and correcting. Human Factors, 1996; 38(2):206-219.
7. Coskun M. The Approach of Project-Based Learning in Geography Education, (Unpublished PhD. Thesis). Ankara, Gazi University, 2004.

8. Demirhan C, Demirel O. The approach of project-based learning in program Development, Journal of Abant Izzet Baysal University Faculty of Education, 2003; 3(5):48-61.

9. Erdem M, Akkoyunlu B. A Study on the Project-Based Learning Approach Carried Out with Fifth Grade Students within the Scope of Primary Education Social Studies, İlkogretim-Online, 2002; 1(1): 2-11.

10. Haliloglu Z, Asan A. The Effectiveness of the Project-Based Learning Method in the Computer Course given in Primary Education Secondary Stage Schools, 12. Educational Sciences Conference Proceedings Book, pp.2, Ankara, 2004.

11. Howell RT. The importence of the project method in technology education. Journal of Industrial Teacher Education, 2003; 40(3).

12. Kalayc1 N. A Project-based learning application -example in higher education. Education and Science, 2008; 33(147):85105.

13. Knoll M. The project method. Journal of Industrial Teacher Education, 1997; (3):59-80.

14. Korkmaz H. Alternative Evaluation Approaches in Science And Technology Education, Ankara; Yeryuzu Press, 2004.

15. Lee CI, Tsai FY. Internet project-based learning environment: the effects of thinking styles on learning transfer, Journal of Computer Assisted Learning, 2004; 20(1):31-39

16. Moti F, Abigail B. Integrating alternative asseement in a project based learning course for pre- service science and technology teachers. Assesment and Evaluatinon in Higher Education, 2004; 29(1):41-61.

17. Polat H. The Effect of Management and Monitoring Systems in Project-Based Learning on Student Success Levels and Student Attitudes, (Unpublished master thesis). Elazig, Firat University, 2011.

18. Saban A. The Process of Teaching Learning, Improved $2^{\text {nd }}$ Edition, Ankara: Nobel Press, 2002.

19. Saracaloglu AS, Akamca GO, Yesildere S. The place of project-based learning in primary education, Gazi University Turkish Education Science Journal, 2006; 4(3).

20. Sezgin F. The Effect of Project Based Learning and Portfolio Evaluation on the Students Achievement and Attitude Levels, (Unpublished master thesis). Zonguldak Karaelmas University, 2008.

21. Taskin O, Apaydin Z, Aydin H, Cakici Y, Gemici O, Irez S, Kose S, Matyar F, Ozsevgec T, Peker D, Saka AZ, Tas E, Turgut H. Novel Approaches in Science and Technology Education, Ankara: Pegema Press, 2008.

22. Thomas JW. A Review of Research on Project Based Learning. http://www.bie.org/tmp/research/researchreviewPBL.pdf. Access: 15.5.2018.

23. Yurtluk M. The Effect of the Project-Based Learning Approach on Student Attitudes and the Learning Process $n$ Mathematics, (Unpublished master thesis). Ankara Hacettepe University, 2003. 